\title{
ANALISIS KAPASITAS DRAINASE SEBAGAI UPAYA PENGENDALIAN BANJIR DI KELURAHAN SANGKRAH, SURAKARTA
}

\author{
Imam Nor Sholi ${ }^{1}$, Rintis Hadiani ${ }^{2}$, Endah Sitaresmi Suryandari ${ }^{3)}$ \\ 1) Mahasiswa Fakultas Teknik, Prodi Teknik Sipil, Universitas Sebelas Maret \\ 2) Pengajar Fakultas Teknik, Prodi Teknik Sipil, Universitas Sebelas Maret \\ 3) Kepala Dinas Pekerjaan Umum Kota Surakarta \\ Jl. Ir. Sutami 36A, Surakarta 57126; Telp. 0271-634524. \\ Email:imamsholi@gmail.com
}

\begin{abstract}
Sangkerah subdistrict is located in Pasar Kliwon district, Surakarta City. Sangkerah subdistrict is passed by a Pepe Hilir river and Jenes river. In the riverbank area there are frequent flooding and inundation. As an effort to control floods is analysis of the drainage of Sangkrah subdistrict. Drainage system analysis is calculated using the Hydrograph Method Soil Conservation Service Synthesis Unit. Flood routing analysis is performed with the HEC-RAS software with unsteady flow. From the mapping results, it is obtained the volume of floods treated by Excel. Whereas the peak discharge of the drainage channel is calculated by the manning formula.

The results of this study indicate that the abundant flood volume of the Pepe Hilir river due to Q5 is 1943,7 $\mathrm{m} 3$ / hour, due to Q10 is 2714,1 m3 / hour, due to Q25 of 3278,4 m3 / hour, and the result of maximum twoday rainfall is 8795,8 m3 / hour. Drainage planned under normal conditions has a capacity of 1013066,96 m3 I hour from these results it can be concluded that the dimensions of the drainage channel plan can accommodate the volume of flooding that occurs in return periods of 5 years, 10 years, 25 years, and 2 days of rain.
\end{abstract}

Key words: Flood, Drainage, HEC_RAS

\begin{abstract}
Abstrak
Kelurahan Sangkrah berada di Kecamatan Pasar Kliwon Kota Surakarta. Kelurahan Sangkrah dilewati oleh Sungai Pepe Hilir dan Kali Jenes. Pada bantaran sungai sering terjadi banjir dan genangan. Salah satu cara untuk upaya pengendalian banjir adalah dengan menganalisis sistem kerja drainase di Kelurahan Sangkrah. Analisis sistem drainase dihitung dengan metode Hidrograf Satuan Sintesis Soil Conservation Service. Analisis flood routing dilakukan dengan software HEC-RAS dengan aliran unsteady flow. Dari hasil pemetaan itu didapatkan volume banjir yang diolah dengan excel. Sedangkan debit puncak saluran drainase dihitung dengan rumus manning.

Hasil analisis penelitian menunjukkan bahwa volume banjir yang melimpah dari Sungai Pepe Hilir akibat Q5 sebesar 1943,7 m3/jam, akibat Q10 adalah sebesar 2714,1 m3/jam, akibat Q25 sebesar $3278,4 \mathrm{~m} 3 / \mathrm{jam}$, dan akibat Hujan dua harian maksimum adalah sebesar 8795,8 m3/jam. Drainase yang direncanakan dalam keadaan normal memiliki kapasitas tampung sebesar 1013066,96 m3/jam dari hasil tersebut dapat disimpulkan bahwa dimensi saluran drainase rencana dapat menampung volume banjir yang terjadi pada periode ulang 5 tahun, 10 tahun, 25 tahun, dan hujan 2 harian.
\end{abstract}

Kata kunci: Banjir, Drainase, $H E C-R A S$

e-Jurnal MATRIKS TEKNIK SIPIL/Juni 2020/256 


\section{PENDAHULUAN}

Kota Surakarta yang secara geografis terletak di lembah dan tempuran sungai menyebabkan mudah sekali terjadi banjir. Potensi banjir dapat dipicu karena adanya luapan air sungai maupun drainase yang memiliki kapasitas kurang memadai, sehingga dapat merugikan bagi penduduk yang langsung terkena dampaknya. Tugas utama saluran drainase yaitu mengalirkan air dari satu tempat ke tempat yang lain bisa mengalami penurunan kinerja. Hal ini disebabkan oleh berbagai faktor seperti, kapasitas yang semakin mengecil, akses antar saluran yang kurang memadai, tersumbat, dan lain-lain.

Banjir termasuk peristiwa alam yang terjadi karena kapasitas tampungan saluran atau sungai tidak mampu menampung volume air yang melebihi kapasitas tampungan, sehingga terjadi luapan air di wilayah sekitar sungai. Banjir biasanya dapat terjadi karena curah hujan yang tinggi, penyempitan saluran, penggunaan tata guna lahan yang salah, sedimentasi yang tinggi, atau arus balik (Rintis, 2014)

Kelurahan Sangkrah merupakan salah satu wilayah Kota Surakarta yang sering mengalami banjir. Akibat kurang berfungsinya saluran drainase membuat dampak banjir di Kelurahan Sangkrah. Apabila terjadi hujan dengan intensitas tinggi dengan durasi yang lama dapat mengakibatkan luapan air dari saluran drainase dikarenakan kapasitas yang mengecil dan kurang adanya akses ke sungai utama.

Penelitian ini melanjutkan dari penelitian sebelumnya berjudul "Penelusuran banjir Berdasarkan Analisis Metode Kinematik Berbasis Sistem Informasi Geografis (SIG) di Kelurahan Sangkrah, Surakarta". Pada penelitian sebelumnya mendapatkan hasil yaitu debit banjir maksimum Sungai Pepe Hilir untuk kala ulang Q5 , Q10, Q25, dan Q50. Selain itu juga didapatkan ketinggian muka air banjir, luasan, dan durasi daerah tergenang. Data-data tersebut selanjutnya dipakai sebagai acuan dalam menganalisis kapasitas saluran drainase.

\section{LANDASAN TEORI \\ Dasar Teori}

Banjir merupakan suatu peristiwa dimana debit aliran air sungai berlebih dari debit biasanya akibat hujan di suatu wilayah secara terus menerus dalam kurun waktu tertentu hingga tidak dapat ditampung oleh alur sungai sehingga terjadi limpahan keluar sungai dan menggenangi kawasan disekitarnya (Peraturan dirjen RLPS No. 4 Tahun 2009 ). Aliran banjir yang terjadi dapat disebabkan karena faktor kinerja yang kurang maksimal pada saluran drainase di Kelurahan Sangkrah yang tidak dapat bekerja dengan baik. Hal ini bisa disebabkan berbagai macam masalah seperti sedimentasi, dimensi saluran yang tidak memadai, dan lain-lain. Dalam penelitian ini sudah terdapat rancangan dimensi saluran drainase yang disediakan oleh DPUPR Surakarta, sehingga untuk menguji keefektifan desain tersebut dilakukan analisis banjir dan perhitungan kapasitas saluran dari rancangan tersebut.

Hujan merupakan komponen terpenting dalam analisis hidrologi. Hujan yang turun merupakan sumber utama yang akan melimpas ke sungai. Jumlah dan sebaran hujan yang terjadi dicatat dalam suatu alat penakar hujan yang diletakkan di tempat-tempat tertentu (bambang Triatmodjo, 2009).

Hidrograf Satuan Sintetis merupakan program aplikasi yang mengintegrasikan fitur graphical user interface, analisis hidraulik, manajemen dan penyimpanan data, grafik, serta pelaporan. Dalam penelitian ini aliran yang digunakan adalah aliran unsteady.

\section{METODE PENELITIAN}

Penelitian ini menggunakan data sekunder. Data sekunder meliputi data hujan harian stasiun Hujan Mojolaban, baki dan Pabelan, data situasi sungai Pepe Hilir, peta kontur Kota Surakarta dan peta DAS Pepe Hilir.

\section{HASIL DAN PEMBAHASAN}

\section{Daerah Aliran Sungai}

Daerah Aliran Sungai (DAS) merupakan daerah tangkapan air yang masuk kedalam sungai. Untuk analisis banjir pada Kelurahan Sangkrah diperlukan wilayah DAS, yaitu DAS Pepe Hilir. DAS PepeHilir disajikan dalam Gambar 1 


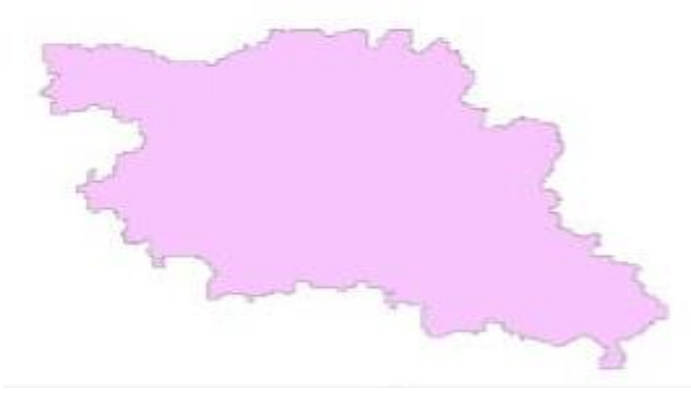

Gambar 1 Daerah Aliran Sungai Pepe Hilir

\section{Uji Kepanggahan}

Uji kepanggahan dilakukan dengan metode kurva massa ganda (double mass curve). Uji kepanggahan dilakukan dengan cara merekap data hujan tahunan selama 20 tahun terakhir, dari mulai tahun 1998 sampai dengan tahun 2018. Dalam perhitungan ini meliputi data hujan tahunan Stasiun Mojolaban, Stasiun Baki, dan Stasiun Pabelan. Data curah hujan yang digunakan adalah curah hujan maksimum tahunan Grafik kurva massa ganda merupakan hasil dari perbandingan komulatif hujan tahunan masing-masing stasiun hujan. Data hujan dapat dikatakan panggah apabila memiliki nilai determinastik $\left(\mathrm{R}^{2}\right)$ yang mendekati 1 atau mendekati linier. Dari analisis dengan excel di dapat Gambar 2 sampai Gambar 4.

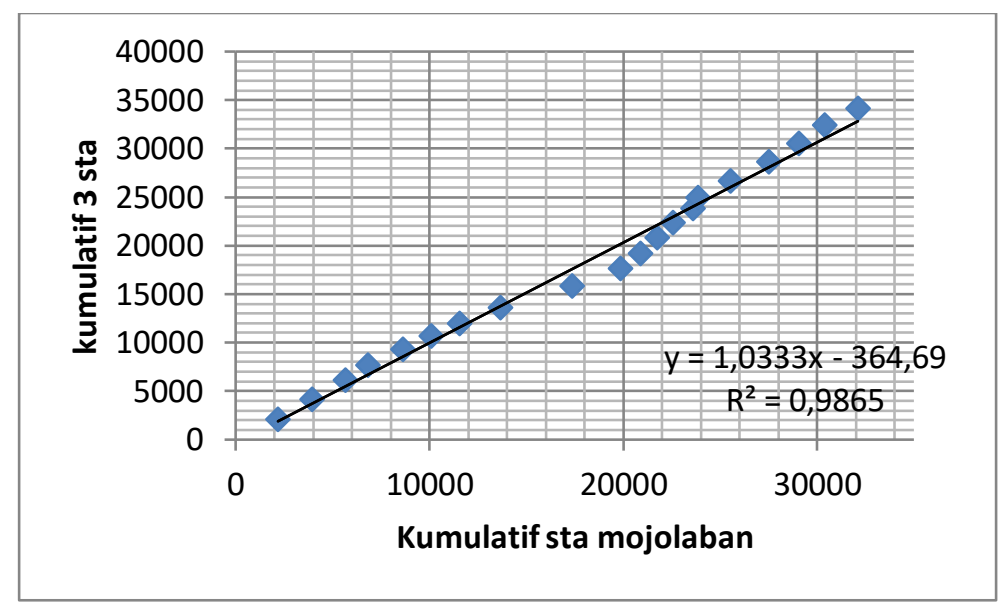

Gambar 2 Kurva Massa Ganda dari Sta Mojolaban

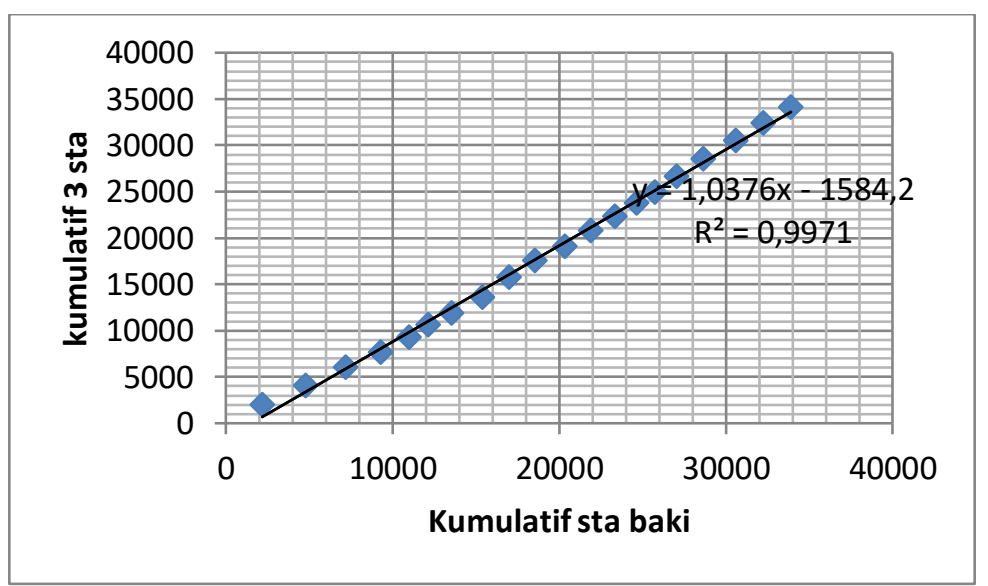

Gambar 3 Kurva Massa Ganda dari Sta baki 


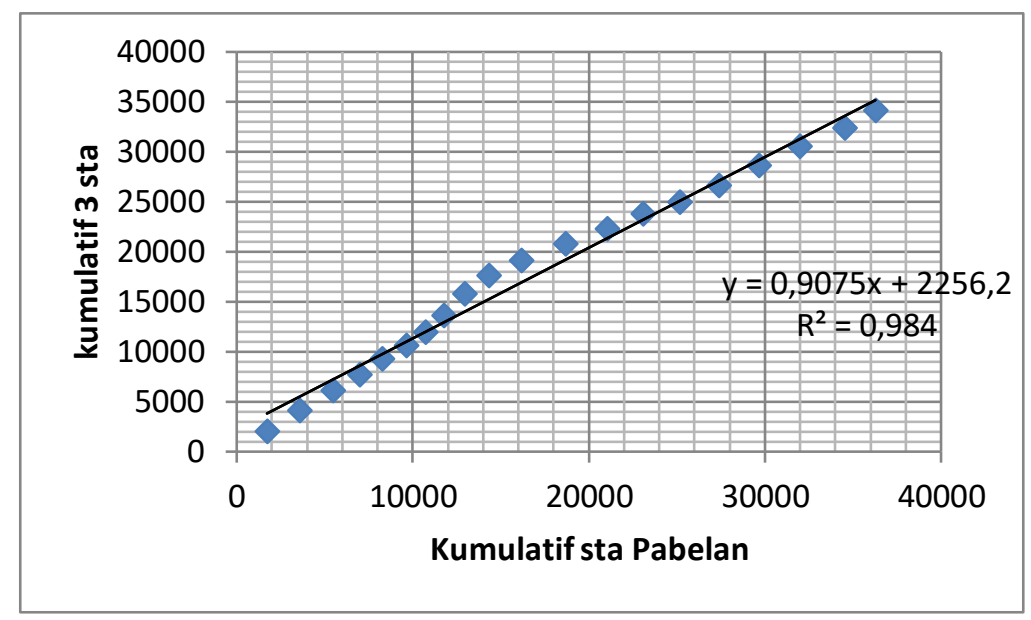

Gambar 4 Kurva Massa Ganda dari Sta Pabelan

\section{Hujan Kawasan}

Hujan kawasan dianalisis menggunakan metode rata-rata aljabar dengan data hujan maksimum harian. Metode ratarata aljabar merupakan metode yang paling sederhana, yaitu dengan cara menjumlahkan besarnya hujan dibagi dengan jumlah stasiun hujan, yang kemudian dipilih nilai yang terbesar dari hujan harian maksimum tiap stasiun untuk menjadi hujan maksimum kawasan. Untuk hujan kawasan dua harian di analisis dengan metode rata-rata aljabar seperti pada hujan kawasan harian maksimum.

\section{Distribusi Hujan}

Dari analisis distribusi hujan menggunakan metode Log Person III yang didasarkan pada SNI 2415-2016 tentang Tata Cara Perhitungan Debit Banjir Rencana. Analisis distribusi hujan Log Person III didapatkan hasil seperti dalam Tabel 1

Tabel 1 Tabel Log Person III

\begin{tabular}{|c|c|c|c|c|c|c|}
\hline \multicolumn{7}{|c|}{ Log Person III } \\
\hline NO & TAHUN & $\mathbf{X}$ & Log X & $\mathbf{X - X t}$ & $\mathbf{( X - X t )}^{\wedge} \mathbf{2}$ & $\mathbf{( X - X t )})^{\wedge} \mathbf{3}$ \\
\hline 1 & 1999 & 102,33 & 2,0100 & 0,2292 & 0,0525 & 0,0120 \\
\hline 2 & 2000 & 61,33 & 1,7877 & 0,0069 & 0,0000 & 0,0000 \\
\hline 3 & 2001 & 84,67 & 1,9277 & 0,1469 & 0,0216 & 0,0032 \\
\hline 4 & 2002 & 63,61 & 1,8035 & 0,0227 & 0,0005 & 0,0000 \\
\hline 5 & 2003 & 63,00 & 1,7993 & 0,0185 & 0,0003 & 0,0000 \\
\hline 6 & 2004 & 67,33 & 1,8282 & 0,0474 & 0,0022 & 0,0001 \\
\hline 7 & 2005 & 32,00 & 1,5051 & $-0,2757$ & 0,0760 & $-0,0209$ \\
\hline 8 & 2006 & 59,67 & 1,7757 & $-0,0051$ & 0,0000 & 0,0000 \\
\hline 9 & 2007 & 103,00 & 2,0128 & 0,2320 & 0,0538 & 0,0125 \\
\hline 10 & 2008 & 42,00 & 1,6232 & $-0,1576$ & 0,0248 & $-0,0039$ \\
\hline 11 & 2009 & 71,67 & 1,8553 & 0,0745 & 0,0056 & 0,0004 \\
\hline 12 & 2010 & 48,00 & 1,6812 & $-0,0996$ & 0,0099 & $-0,0010$ \\
\hline 13 & 2011 & 47,00 & 1,6721 & $-0,1087$ & 0,0118 & $-0,0013$ \\
\hline 14 & 2012 & 73,67 & 1,8673 & 0,0865 & 0,0075 & 0,0006 \\
\hline 15 & 2013 & 43,00 & 1,6335 & $-0,1473$ & 0,0217 & $-0,0032$ \\
\hline
\end{tabular}




\begin{tabular}{|c|c|c|c|c|c|c|}
\hline 16 & 2014 & 54,00 & 1,7324 & $-0,0484$ & 0,0023 & $-0,0001$ \\
\hline 17 & 2015 & 84,45 & 1,9266 & 0,1458 & 0,0213 & 0,0031 \\
\hline 18 & 2016 & 45,67 & 1,6596 & $-0,1212$ & 0,0147 & $-0,0018$ \\
\hline \multicolumn{7}{|c|}{ Log Person III } \\
\hline NO & TAHUN & $\mathbf{X}$ & $\log X$ & $\mathrm{X}-\mathrm{Xt}$ & $(X-X t)^{\wedge} 2$ & $(\mathrm{X}-\mathrm{Xt})^{\wedge} 3$ \\
\hline 19 & 2017 & 68,00 & 1,8325 & 0,0517 & 0,0027 & 0,0001 \\
\hline \multirow[t]{6}{*}{20} & 2018 & 48,09 & 1,6821 & $-0,0987$ & 0,0098 & $-0,0010$ \\
\hline & \multicolumn{2}{|c|}{ Jumlah } & 35,6160 & 0,0000 & 0,3391 & $-0,0011$ \\
\hline & \multicolumn{2}{|c|}{ Rerata } & 1,7808 & & & \\
\hline & \multicolumn{2}{|c|}{ S.dev } & 0,1336 & & & \\
\hline & \multicolumn{2}{|c|}{ Kemencengan } & $-0,0001$ & & & \\
\hline & \multicolumn{2}{|c|}{ CS } & $-0,0258$ & & & \\
\hline
\end{tabular}

Tabel 1 Lanjutan

\section{Uji Kecocokan Distribusi Hujan}

Uji kecocokan distribusi hujan dilakukan untuk mengetahui kecocokan antara metode perhitungan dengan data hujan. Dalam penelitian ini dilakukan uji kecocokan dengan metode Smimov Kolmogorov dengan tingkat ketelitian 5 $\%$. Berdasarkan hasil uji Sminov-Kologorov pada Tabel 4.6 diperoleh $\Delta$ maksimum $=0,07$, dan dibandingkan dengan Tabel 3.2 untuk jumlah data hujan (n) sebanyak 20 tahun maka akan didapatkan $\Delta$ kritis $=0,29$. Dengan syarat $\Delta$ maksimum $<\Delta$ kritis, maka distribusi hujan dapat diterima berdasarkan uji Smirnov-Kolmogorv.

\section{Hujan Periode Ulang}

Perhitungan hujan periode ulang dengan cara mengembalikan nilai logaritma dari distribusi hujan tersebut. Hasil perhitungan hujan periode ulang disajikan dalam Tabel 2.

Tabel 2 Hujan Periode Ulang

\begin{tabular}{|c|c|c|c|c|}
\hline KALA ULANG & K & K.SDEV & Xt+K.Sd & Qt(mm/jam) \\
\hline 5 & 0,8448 & 0,11 & 1,89 & 78,28 \\
\hline 10 & 1,2806 & 0,17 & 1,95 & 89,51 \\
\hline 25 & 1,7445 & 0,23 & 2,01 & 103,24 \\
\hline
\end{tabular}

Hidrograf Satuan Sintetis

Dari hasil debit jam-jaman SCS periode ulang 5, 10, dan 25 tahun maka dapat dibuat grafik hidrograf SCS. Grafik hidrograf untuk periode ulang Sungai Pepe Hilir di tampilkan dalam Gambar 5. 


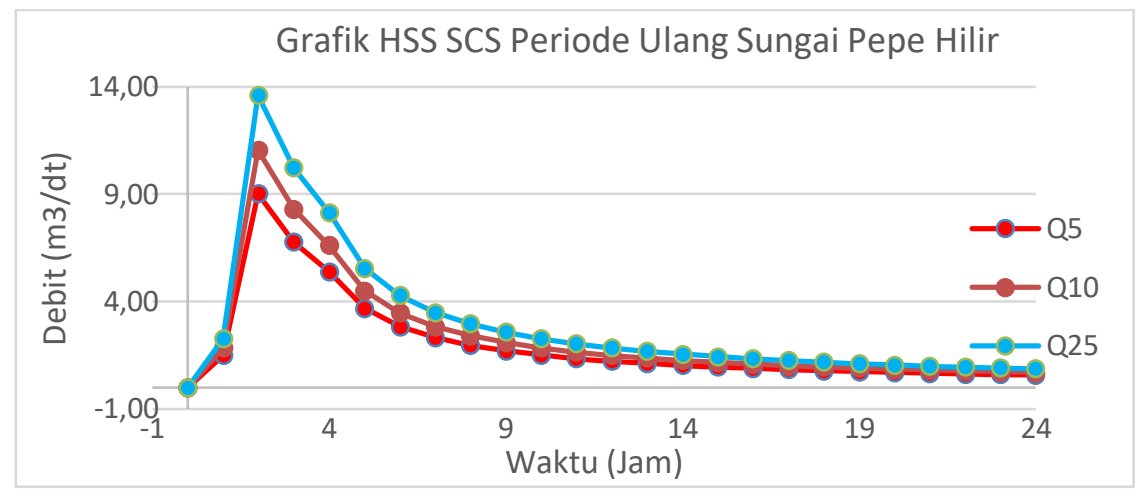

Gambar 5 HSS SCS Pepe Hilir

Dari hasil debit jam-jaman SCS periode ulang 5, 10, dan 25 tahun maka dapat dibuat grafik hidrograf SCS. Grafik hidrograf untuk periode ulang Sungai Jenes di tampilkan dalam Gambar 6.

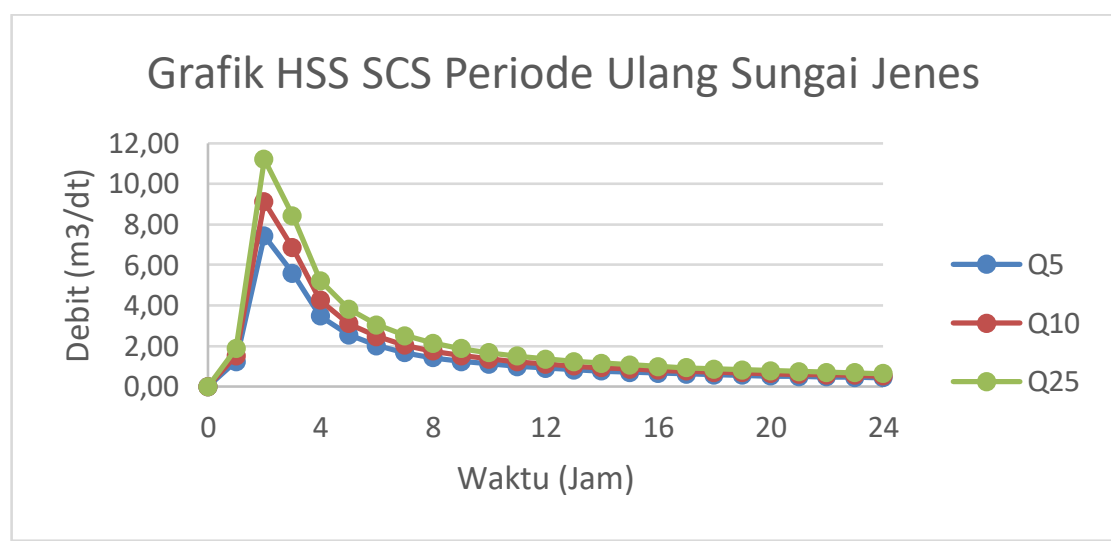

Gambar 6 HSS SCS Sungai Jenes

\section{Analisis Banjir}

Analisis banjir pada Kelurahan Laweyan dilakukan dengan HEC-RAS. HEC-RAS mengelola data geometry dan debit aliran sungai menjadi ketinggian, durasi dan pemetaan banjir. HEC-RAS menganalisis secara Hidrolika, dengan simulasi aliran unsteady flow.

\section{Pemetaan Banjir}

Berdasarkan hasil running HEC-RAS didapatkan ketinggian genangan pada tiap cell serta waktu genangan.
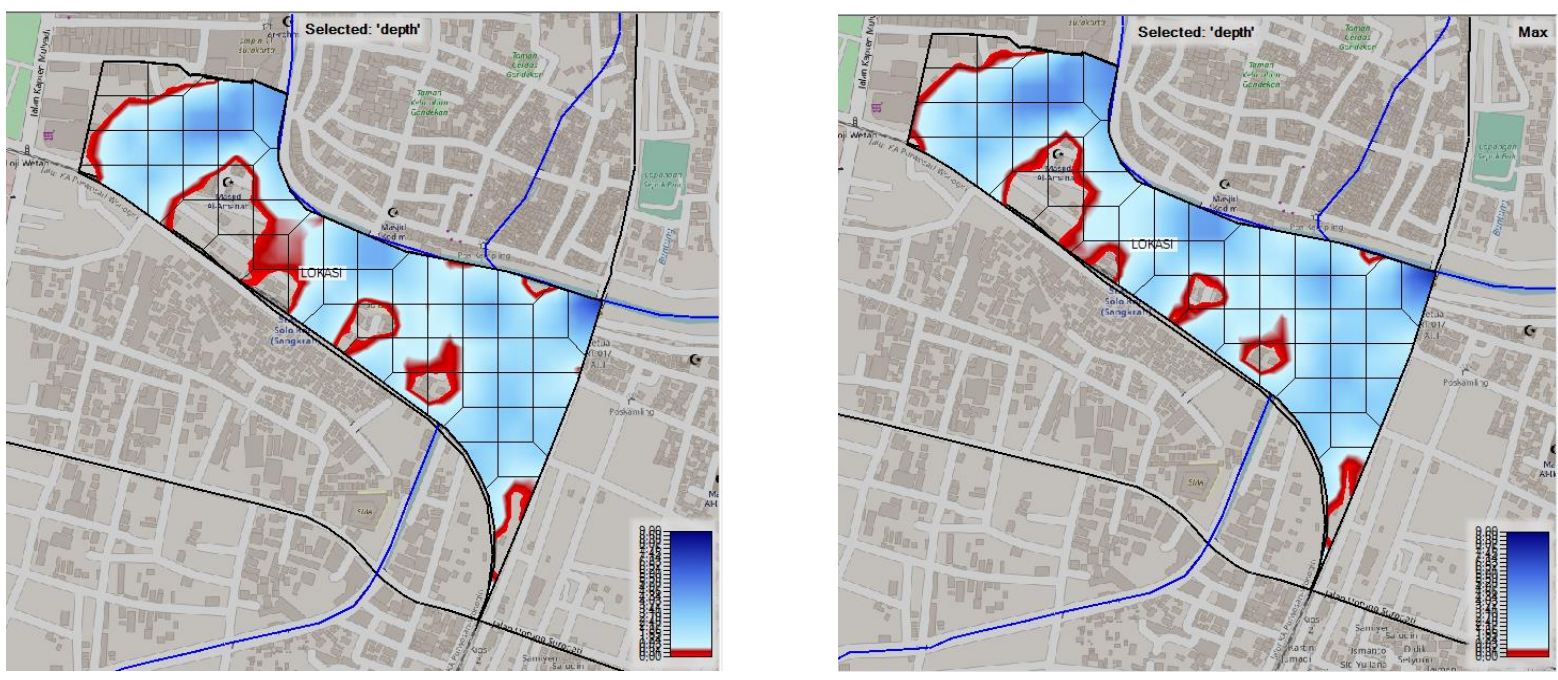
Gambar 7 Banjir yang Terjadi pada Debit Periode Ulang 5 Tahun

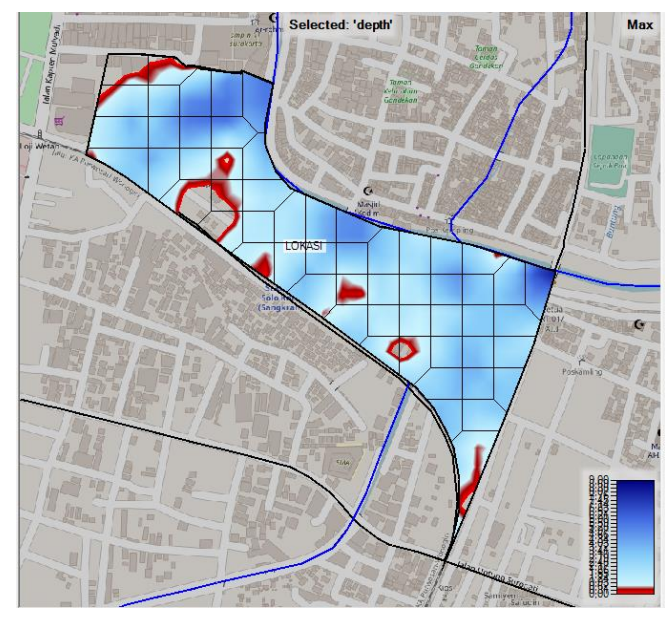

Gambar 9 Banjir yang Terjadi pada Debit Periode Ulang 25 Tahun
Gambar 8 Banjir yang Terjadi pada Debit Periode Ulang 10 Tahun

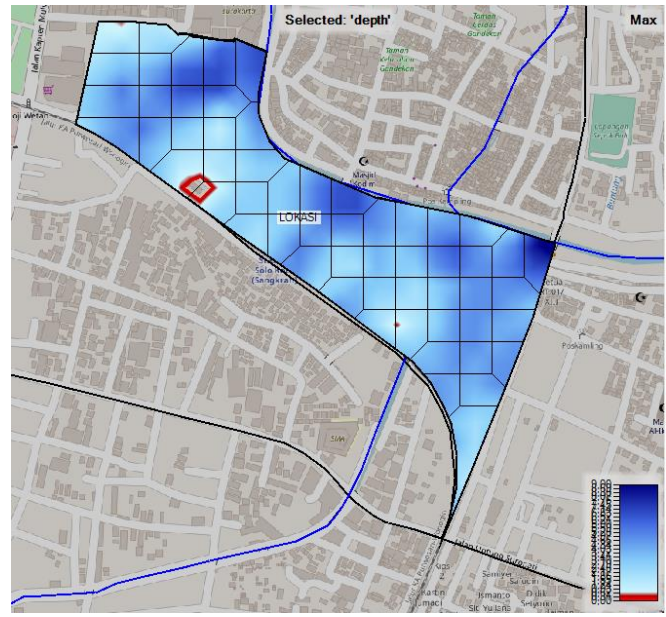

Gambar 10 Banjir yang Terjadi pada Debit Periode Ulang 2 harian maksimum

\section{KESIMPULAN}

Berdasarkan hasil analisis dan pembahasan maka dapat diambil beberapa kesimpulan sebagai berikut:

1 Debit banjir maksimum Sungai Pepe Hilir untuk periode ulang $Q_{5}$ tahun sebesar 9,021 m³ $/ \mathrm{s}$; $\mathrm{Q}_{10}$ tahun sebesar 11,054 m³/s; Q 25 tahun sebesar 13,606 m³ $/ \mathrm{s}$; dan banjir 2 harian maksimum sebesar 17,309 m³/s. Sedangkan debit banjir maksimum Sungai Jenes untuk periode ulang $Q_{5}$ tahun sebesar 7,437 m³ $/ \mathrm{s}$; $\mathrm{Q}_{10}$ tahun sebesar $9,113 \mathrm{~m}^{3} / \mathrm{s} ; \mathrm{Q}_{25}$ tahun sebesar $11,217 \mathrm{~m}^{3} / \mathrm{s}$; dan banjir 2 harian maksimum sebesar 13,974 $\mathrm{m}^{3} / \mathrm{s}$.

2 Hasil analisis Unsteady Flow dari durasi dan elevasi banjir limpasan sungai yang terjadi di Kelurahan Sangkrah menggunakan Hec-RAS dengan Debit periode ulang 10, 25 tahun serta 2 harian maksimum ditampilkan pada Tabel 4.

Tabel 3 Hasil Analisis Unsteady Flow untuk Durasi, dan Elevasi Banjir Limpasan

\begin{tabular}{|c|c|c|c|c|}
\hline Debit Banjir & $\begin{array}{c}\text { Volume Limpasan } \\
\text { Ketinggian 0-5 m } \\
(\mathrm{m} 3)\end{array}$ & $\begin{array}{c}\text { Waktu Rata- } \\
\text { rata Genangan } \\
(\mathrm{Jam})\end{array}$ & $\begin{array}{c}\text { Volume Limpasan } \\
\text { Ketinggian }>30 \mathrm{~cm} \\
(\mathrm{~m} 3)\end{array}$ & $\begin{array}{c}\text { Waktu Rata- } \\
\text { rata Genangan } \\
(\text { Jam })\end{array}$ \\
\hline 5 Tahunan & $1.943,722$ & 19,14 & $1.927,871$ & 17,19 \\
\hline 10 Tahunan & $2.714,129$ & 20,68 & $2.675,159$ & 18,86 \\
\hline 25 Tahunan & $3.278,365$ & 21,04 & $3.278,365$ & 20,09 \\
\hline 2 Harian Maksimum & $8.795,758$ & 43,61 & $8.796,993$ & 43,25 \\
\hline
\end{tabular}

3 Berdasarkan analisis kapasitas saluran drainase rencana dengan rumus manning, didapatkan volume untuk tiap-tiap saluran drainase yang diteliti. Dan setelah dibandingkan dengan besar volume banjir hasil analisis Hec-RAS didapatkan hasil sebagai berikut.

Tabe1 4. Analisis Volume Banjir dengan Kapasitas Saluran Drainase Rancangan Kelurahan Sangkrah

\begin{tabular}{|c|c|c|c|c|}
\hline Debit Banjir & $\begin{array}{c}\text { Volume Limpasan } \\
\text { Ketinggian 0-5 m } \\
(\mathrm{m} 3)\end{array}$ & $\begin{array}{c}\text { Volume Limpasan } \\
\text { Ketinggian }>30 \mathrm{~cm} \\
(\mathrm{~m} 3)\end{array}$ & $\begin{array}{c}\text { Volume Tam- } \\
\text { pung Drainase } \\
(\mathrm{m} 3)\end{array}$ & $\begin{array}{c}\text { Volume } \\
\text { Genangan } \\
(\mathrm{m} 3)\end{array}$ \\
\hline Q5 & $1.943,722$ & $1.927,8705$ & 1013066,9624 & 0 \\
\hline Q10 & 2714,1285 & $2.675,1590$ & 1013066,9624 & 0 \\
\hline Q25 & $3.278,365$ & $3.278,3645$ & 1013066,9624 & 0 \\
\hline
\end{tabular}




\begin{tabular}{|c|c|c|c|c|}
\hline 2 Harian Maks. & $8.795,758$ & $8.796,9930$ & 1013066,9624 & 0 \\
\hline
\end{tabular}

Sehingga dari Tabel diatas dapat disimpulkan bahwa di wilayah Kelurahan Sangkrah tidak terjadi banjir, dikarenakan dimensi saluran drainase rencana dapat menampung dan mengalirkan volume banjir limpasan sungai untuk Periode Ulang $\mathrm{Q}_{10}, \mathrm{Q}_{25}$ dan hujan 2 harian.

\section{REKOMENDASI}

1. Tersedianya data peta digital yang lebih detail,

2. Tersedia peta kontur yang lebih rapat,

3. Memperhitungkan saluran drainase yang ada,

4. Memperhitungkan aliran yang masuk,

5. Mempertimbangkan adanya bangunan di sekitar sungai, agar dapat membuat peta genangan yang lebih akurat dan estimasi kerusakan bangunan

\section{REFERENSI}

Al Kahfi, M.A.K.M., 2014. Studi Sistem Drainase Resapan Untuk Penanggulangan Banjir Di Lingkungan Iii, Pasar Iii, Padang Bulan, Medan. J. Tek. Sipil USU 3.

Anonim. 2014. Peraturan Menteri Pekerjaan Umum Nomor 12/PRT/M/2014 Tentang Penyelenggaraan Sistem Drainase Perkotaan.

Ishadi, N.K., Hadiani, R.R.R., Suryandari, E.S., 2018. Penelusuran Banjir Berdasarkan Analisis Metode Kinematik Berbasis Sistem Informasi Geografis (SIG) Di Kelurahan Sangkrah, Surakarta. Matriks Teknik Sipil 6.

Jadmiko, Sigit. Hadiani, Rintis, dan Saido, Agus Prijadi. 2013. Banjir Tahunan Sub Daerah Aliran Sungai Bengawan Solo Hulu 3 dengan Sistem Informasi Geografis. Fakultas Teknik. Universitas Sebelas Maret. Surakarta.

Kamaruzzaman, R., 2010. Desain Saluran Drainase Bandara Udara Juwata Kota Tarakan-Kalimantan Timur.

Kusnan, K., 2010. Menanggulangi Genangan Air Hujan Yang Terjadi Di Jalan Raya Wiyung Pada Drainase Perkotaan Gunungsari Surabaya Barat. Waktu 8, 47-59.

Kusuma Dewi, A., Setiawan, A., P Saido, A., 2014. Evaluasi Sistem Saluran Drainase Di Ruas Jalan Solo Sragen Kabupaten Karanganyar. Matriks Tek. Sipil 2, 170.

Marzuki, R., 2017. Analisa Dimensi Saluran Terbuka Guna Menanggulangi Banjir Tahunan (Studi Kasus Di Jl. Jend A. Yani-Jl. Mayjend Sutoyo). Kurva S 4, 137-145.

Priyo, Dimas Arry. 2016. Analisis Kinerja Pintu Air dan Pompa Demangan di Kota Surakarta. Tesis Magister, Program Studi Teknik Sipil, Program Pascasarjana, Universitas Sebelas Maret, Surakartara

Ps, M.M.A., Gultom, R.A.P., Suripin, S., Kurniani, D., 2014. Perencanaan Sistem Drainase Kali Tenggang Semarang. J. Karya Tek. Sipil 3, 240-248.

Qurniawan, A.Y., 2010. Perencanaan Sistem Drainase Perumahan Josroyo Permai Rw 11 Kecamatan Jaten Kabupaten Karanganyar (Phd Thesis). Universitas Sebelas Maret.

Raharjo, I., 2014. Evaluasi Penyebab Genangan Banjir Wilayah Perkotaan Pringsewu Berdasarkan Dimensi Saluran Drainase Eksisting. J. Ilm. Tek. Pertan.-Tektan 6, 179-189.

Rintis Hadiani, 2014, Penelusuran Banjir di DAS Temon Dengan Metode Muskingum-Cunge Menggunakan Hidrocad, Skripsi, Jurusan Teknik Sipil, Universitas Sebelas Maret, Surakarta.

Supriyani, E., Bisri, M., Dermawan, V., 2013. Studi Pengembangan Sistem Drainase Perkotaan Berwawasan Lingkungan (Studi Kasus Sub Sistem Drainase Magersari Kota Mojokerto). J. Tek. Pengair. 3, 112-121.

Suripin. 2004. Sistem Drainase Perkotaan yang Berkelanjutan. Yogyakarta. Andi Offset.

Triatmodjo, Bambang. 2009. Hidrologi Terapan.Yogyakarta:Beta Offset.

Vigiyanto, A., 2014. Analisis Normalisasi Saluran Drainase Kecamatan Kota Di Kabupaten Tuban. Rekayasa Tek. Sipil 2. 